\title{
Lifting the veil: Unpacking the discourse of water scarcity in Jordan
}

\begin{abstract}
This article investigates the construction of the discourse of water scarcity in Jordan. It identifies the actors constructing the discourse and the elements comprising the discourse. The study is important and makes an original contribution because while the issue of water scarcity in Jordan has been widely researched, it has been done mainly with engineering approaches, the discourse of water scarcity has been taken for granted, and studies on an in depth discursive analysis of the issue of water scarcity in Jordan are still missing. The study finds that there is a single dominant discourse of water scarcity, which is composed of two narratives: water insufficiency and water mismanagement. The water insufficiency narrative is constructed to emphasise factors external to the responsibility of the Jordanian government as reasons for water scarcity, like nature, refugees, and neighbouring countries. It is mainly constructed by governmental oriented actors and deployed to open solutions on the supply and conservation sides and ultimately to maintain the status quo of the current water uses. The water mismanagement narrative is constructed to emphasise as reasons for water scarcity factors of mismanagement of water resources, and deployed to increase economic efficiency in the water sector.
\end{abstract}

\section{Keywords:}

Jordan; hydropolitics; water scarcity; water security; discourse theory; discourse 


\section{INTRODUCTION: MAPPING THE DISCOURSE}

To solve an issue, we first need to be clear about what the problem we are trying to solve is. Consequently, in order to respond to water scarcity and to manage the water governance at the local, national, and transboundary level, it is necessary to understand the reasons behind water scarcity. This would allow building sustainable, efficient, and effective capacity for integrated water management able to create new opportunities for cooperation, community and peace building, and conflict management.

As shown by Feitelson (2002), Mehta (2001), Alatout (2008), Selby (2003), and Edwards (2013), discourses of water scarcity are key to shape people's understanding of the issue - the causes behind water scarcity - and therefore how to solve it, meaning the policies in the water sector. Given the importance of the discourse of water scarcity, it is necessary to examine who constructs the discourse and how, revealing in this way their interests, and the policy solutions their discourse of water scarcity opens (or closes). Thus, an interdisciplinary approach is key to understanding the discourse of water scarcity and proposed policy approaches, and why certain policies are strongly supported while others are not.

In Jordan, water has been extensively studied by engineers, while little research has adopted a discourse analysis approach to water scarcity in the country. Hussein (2017b; 2018a) showed how the discourse of water scarcity is constructed in the Jordanian educational system and the role of the discourse in shaping transboundary water governance; Bonn (2013) discussed the role of the donors' community in the Jordanian water politics; Yorke (2016) investigated the role of the shadow state in the Jordanian water sector. This article contributes to the literature on water scarcity in Jordan by providing an in-depth analysis on the discourse of water scarcity in Jordan, providing insights on the different causes of water scarcity in the country. This is important as it will allow policy makers and the donors community to better understand the nuances of reasons behind the issue of water scarcity, providing them with the tools to better design sustainable and inclusive policies to solve the issue of water scarcity. This is an important novel contribution because previous studies on water resources in Jordan did not explore the construction of the discourse of water scarcity and did not adopt a discourse analysis approach to the topic; major studies on water resources, for instance conducted by Salameh and Bannayan (1993) looked at infrastructural water development and at hydrological data, while Haddadin (2006) also explored negotiations and treaties on shared water resources; nevertheless this 
article brings a topical and methodological novelty to the study of water resources in Jordan.

This article deploys elements of the theories on environmental discourse analysis. Environmental discourse theory (Hajer, 1995; Dryzek, 1997) emphasizes the importance of discourses in policy making. Discourses play a central role in shaping environmental policy-making as they legitimise and back certain solutions and discredit and silence others (Leach \& Mearns, 1996). The peculiarity of environmental discourse theory is its direct link between discourses and environmental policy. Policy makers make sense of the complexity of environmental issues through discourses in order to suggest and identify potential solutions to certain issues (Dryzek, 1997: 9-10). For Dryzek (1997), a discourse is "a shared way of apprehending the world; embedded in language it enables those who subscribe to it to interpret bits of information and put them together into coherent stories or accounts," thus legitimising knowledge and justifying environmental policies (Dryzek, 1997: 8).

This article is guided by the following research question: What are the elements comprising the discourse of water scarcity, including narratives and sub-narratives? After conducting the analysis of the interviews, focus groups, and documents collected during fieldwork, the discourse of water scarcity in Jordan emerged as being comprised by two narratives: water insufficiency and water mismanagement. The analysis showed seven subtypes of rationale within the two categories. Hence, for analytical purposes, as shown in Figure $1^{1}$, this article maps the discourse into two narratives and seven sub-narratives:

- Population growth, immigration, and refugees

- Unfair sharing with neighbouring countries

- Climate change as an additional pressure

- Jordan as an arid and semi-arid region with low precipitation

- Non-Revenue Water: leakages and physical losses

- Non-Revenue Water: illegal wells and illegal uses

- The unsustainable agricultural water use

\footnotetext{
${ }^{1}$ The size of an oval indicates the dominance of the narrative in comparison to the other oval. The size of a circle inside the ovals indicate the dominance of the sub-narrative in comparison to the other circles in the same oval.
} 
Nevertheless, it understands the discourse as fluid and not divided into different parts. ${ }^{2}$ This choice is done, as it is believed that it is necessary to first clearly show how the problem is understood, in order to discern the interests and how the discourses relate to the proposed solutions.

\section{FIGURE 1}

To unpack the water scarcity discourse, after a methodological explanation, this article analyses the sub-narratives of the water insufficiency narrative, identifying which sub-narratives relate to which narrative. Then, it examines those comprising the water mismanagement narrative.

\section{METHODOLOGY}

Data utilised in this article have been collected during fieldwork that took place over ten months in Amman, Jordan, between 2014 and 2015. This research made use of qualitative methods of data collection, with interviews as the main method of inquiry. ${ }^{3}$ The methods of data collection deployed are: document collection, semi-structured interviews, and focus-groups.

- Document collection: texts can produce, reproduce, or contribute to transform a discourse. Hence, key texts, reports, and policies, are central to identify and unpack the discourse of water scarcity in Jordan. Also autobiographies of key figures, former ministers' biographies, academic articles, national policies and strategies, governmental/donors/non-governmental organisations (NGOs) reports and briefings are all key texts that contributes in investigating the discourse of water scarcity. These

\footnotetext{
${ }^{2}$ In fact, the discourse could have been analysed also in other ways, dividing it for analytical purposes not into sub-narratives, but according to other categories to show and highlight other aspects, according to the needs of the analysis. Another way of mapping the discourse is according to the actors constructing them: governmental water insufficiency narrative; and donors and international organisations water mismanagement narrative. Another way of mapping the discourse would be to look at the solutions the narratives suggest.

${ }^{3}$ In order to answer the guiding question, it is firstly needed to clarify my understanding of reality, which is that it cannot be captured objectively and neutrally (Julien, 2012: 45-46). While a material objective reality exists, our understanding of it is mediated, mainly through discourses. For instance, hydrological data provide us with information that need to be made sense of, understood, and interpreted. Hence, knowledge is not objective (Murphy, 1997: 5), but as Von Glasersfeld puts it, "it is made up of the network of things and relationships that we rely on in our living, and on which, we believe, others rely on, too" (Von Glasersfeld, 1995: 7). For Kincheloe, "there is no truly objective way of seeing things" (Kincheloe, 2005: 8). To unpack the different perspectives about water scarcity in Jordan, therefore, I opted for a combination of different methods.
} 
documentations help in understanding how the water scarcity discourse is constructed, reproduced, and cemented.

- Semi-structured interview: this method was extensively employed, as it allows collection of data relevant to understand the interests, the power struggle, and hidden stories within and around the discourse. 106 semi-structured interviews were conducted. This method was used to interview policy-makers and actors involved in constructing or deploying the water scarcity discourse. This kind of interview made it easier to uncover the background stories often hidden to the public, to collect data about on-going negotiations. As water is a high political issue, there are not many available written sources on the Jordanian-Syrian and on the Jordanian-Israeli Joint Water Committees activities or on the current hydropolitical relations. This method also allows collecting data to investigate the reasoning behind specific wording in reports and declarations.

- Focus-groups: this method was employed at the beginning of the fieldwork in order to gauge the general discourses around water scarcity in specific groups, such as farmers, Bedouins, and youth. It was also deployed at the end in order to test and verify the discourses that have been emerging through the analysis of documents and interviews.

The target group for the interviews is as diverse as the data needed to answer the research question. ${ }^{4}$ As shown in Table 1 , in order to investigate the discourse of water scarcity, the target group is: academics, governmental employees, donors' organisations employees, international organisations employees, employees of NGOs, journalists, former and current ministries, members of political parties, diplomats, members of the parliament, employees of water utilities, farmers, Bedouins, and teachers.

\section{TABLE 1}

\footnotetext{
${ }^{4}$ The interviewees I met are the relevant ones as I considered the constituencies and groups they represent, those involved in the different stages of the policy process, and those involved in constructing and reproducing the discourse. For every organisation I tried to interview several people with different roles within the same organisation, in order to capture different perspectives. For instance, concerning the educational system, I have collected and analysed textbooks, interviewed relevant personnel at the Ministry of Education, and teachers and students from different schools and different parts of the country (Hussein, 2017b). Concerning non-revenue water, I have interviewed employees from: donors' organisations, water utility companies, technical unites of the Ministry of Water and Irrigation (MWI), community leaders, water users associations in the Jordan Valley, farmers using legal wells, and those using non-licensed wells.
} 
Initially I interviewed employees of the main Jordanian environmental NGOs, Jordanian academics that published extensively on water resources in Jordan, high level officials from the main relevant governmental institutions, and water managers from donors organisations. During these meetings, I asked them who else in their opinion could be useful to interview on this topic, proceeding therefore with a "snowball system." The interviews aimed at capturing the emphasis that the respondents put on the different causes of water scarcity they mentioned. Hence, they were asked questions like: To what extent there is water scarcity in Jordan? What are the causes behind water scarcity? Why do you think so? These questions allowed identifications of the different causes of water scarcity, and according to how they were answering, also mapping of what causes were felt to be more important than others. The follow up questions also allowed identification of the sources behind their answers; for instance, many youth explained that their knowledge was heavily influenced by textbooks; others by media; and policy makers by specific governmental declarations, conferences, or ministerial reports. A second set of questions explored what, in their opinion, would be the necessary solutions to solve water scarcity.

The interviews were useful also to test the discourses identified after the analysis. During the ten months of fieldwork, I have met multiple times with some of the key expert interviewees, asking them to comment on declarations or pieces or information collected in previous interviews, presenting them anonymously, or about new reports or policies I came across after having met them the first time.

Concerning documentation, I analysed media, academic articles, and reports. As for media, I have considered three national newspapers: The Jordan Times, Al Rai, and Ad-Dustour. The former one is the main newspaper in English in Jordan, while the latter two are the oldest and most widely circulated Arabic newspapers in the country. Concerning academia, I have analysed the academic articles published on the issue of water scarcity in Jordan in the past twenty years, as well as declarations and presentations in academic conferences. Concerning donors, international organisations, and NGOs, I have considered the reports of the organisations published on the issue of water scarcity and water policy in Jordan. When it comes to governmental reports, I analysed relevant reports and policies of the ministry of water and irrigation (MWI), ministry of environment, and ministry of agriculture.

Finally, discourse analysis has also been deployed for the analysis of the data 
collected. This method of data analysis allowed to identify the discourse, narratives, and sub-narratives, and to test them. Data has been analysed looking for returning patterns and themes seen as causes for water scarcity, while the importance of the different reasons has been measured through the emphasis given to the different causes during the interviews and in the written documentation.

\section{THE WATER INSUFFICIENCY NARRATIVE}

The water insufficiency narrative identifies the reasons for the issue of water scarcity in the limited supply, namely the limited or decreasing water resources and the factors increasing the demand side (Rijsberman, 2006: 6). There are four sub-narratives comprising it. The first one considers population growth, in particular waves of immigration and refugees, as the cause for water scarcity. The second one identifies the unfair sharing over the transboundary water resources with neighbouring countries as the reason for water scarcity. The third one argues that climate change is putting an additional pressure and intensifying the water scarcity in the country. The fourth one describes water scarcity as due to Jordan's natural condition of semi-aridity and aridity and to the low precipitation. For each sub-narrative, this section examines: the actors constructing them and the main texts source of interpretation.

\section{The sub-narrative of population growth, immigration, and refugees}

The first sub-narrative sees the problem of water scarcity as due to the rapidly increasing population, immigration, and waves of refugees. Academics, governmental employees, donors, and international organisations mentioned in all the interviews that a very important reason for water scarcity is population growth (e.g. interviews with governmental personnel 8, 14, 17, 18, 22, 25, and 42, with donors 28, 39, and 45, and with academics $3,4,7,11$ ). This reason was not simply mentioned, but emphasised by the interviewees, in reports, and articles as the biggest issue when it comes to why there is water scarcity in Jordan. As also shown in Table 2, for instance, a former minister of the MWI (interview 52) emphasised that in 1940s only 350,000 people lived in Jordan, "while today about nine million live here, therefore the per capita water share has decreased." A Jordanian professor underlined how "water scarcity has been caused and further exacerbated by the waves of refugees: in 2010 we had a population of about six millions, while today we are closer to ten millions. The resources have not increased. It's logical therefore that the increased demand due to a 
growing population is what brought us to this water scarcity crisis" (interview 11).

TABLE 2

The MWI has also published the "Cost of hosting Syrian refugees on water sector of Jordan" report published in 2013 on the impact of the Syrian refugees on water resources both in the short term and in the long term, considering direct and indirect costs (MWI, 2013: 19-22). This text is often cited as a text supporting this subnarrative by other governmental personnel, academics, and the media. Hana Namrouqa, environmental journalist for The Jordan Times, uncritically reproduces this aspect from the MWI in many articles, stressing the role of the Syrian refugees in increasing the water scarcity in Jordan:

"The deteriorating regional conditions and turmoil have led to waves of hundreds of thousands of refugees flowing into Jordan, pushing it over time from being one of the world's 10 water-poorest countries in the world, to the fourth and now the second, according to ranking by the United Nations, Ministry of Water and Irrigation Spokesperson Omar Salameh told The Jordan Times. [...]. The main challenge to the water sector, according to [the government coordinator for human rights report on challenges the water sector is facing], is the increasing demand for water due to the ongoing influx of Syria refugees into the country" (Namrouqa, 2014d).

Population growth, immigration, and refugees are reasons that are mentioned by donors and international organisations when discussing water scarcity. They acknowledge that population growth is putting a pressure on the water resources. This emerged in interviews 28, 39, 45, and also in several reports including a Japanese International Cooperation Agency (JICA) report that says that "the rapidly increasing population is putting heavy pressure on the limited water resources" (JICA, 2014: 3). However, international organisations and donors recognise that this is adding pressure on water resources in Jordan, but its impact is limited compared to the sub-narrative comprising the water mismanagement narrative, as discussed below (ICRC, 2015: 1617). 
The sub-narrative of unfair sharing with neighbouring countries

On the one hand, from the interviews it emerged that current senior government personnel from the MWI, MoPIC, and the Ministry of Foreign Affairs (MFA) see the problem as lying in the relations with Syria over the Yarmouk (Hussein and Grandi, 2015; 2017; Hussein, 2017c). Instead, those at the Ministry of Agriculture (MoA) were more sceptical with seeing Israel as respecting the equitable and reasonable share of Jordan and saw in both Israel and Syria most of the reason for water scarcity in Jordan. On the other hand, low-ranking governmental employees, individuals, political parties, members of the parliament (MPs), former ministries, farmers associations, and NGOs consider Israel as the main obstacle to having an equitable and reasonable share of the transboundary water flow. This emerged in the interviews, including those with MWI staff (interviews 18 and 42), former MWI ministers (interviews 52 and 63), and NGOs (interview 72). Nevertheless, Mohammad Najjar stated in 2010, when he was minister of the MWI, that "Jordan receives its allocated water shares in full under the JordanIsrael Peace Treaty's second annex" (Namrouqa, 2010a). The current MWI, MFA, and MoPIC senior staff stressed that the problem lies in the relations with Syria, which is not respecting the 1987 bilateral treaty. This is also reported in articles in the newspaper in Arabic Al Rai, which underline that Syria is not giving the right share of the Yarmouk to Jordan, undermining agriculture on the Jordanian side while supporting farmers on the Syrian side (Al Rawashdeh, 2011, 2012a, 2012b). Instead, a former MWI minister (interview 63), as well as a Jordanian NGO (interview 72) argued that the major problem is the 1994 Israel-Jordan peace treaty that does not ensure an equitable and reasonable allocation to Jordan. Adnan Khaddam, head of the Jordan Valley Farmers' Union, argues that Israel is not respecting the 1994 IsraelJordan peace treaty, as "Israel's excessive pumping contravenes the Israel-Jordan peace treaty signed in 1994" and considered therefore taking legal actions against Israel (Miller, 2012).

Only one donor emphasised in an interview (28) this element as a cause for water scarcity, while the other donors interviewed overlooked this aspect. Nimry from The Jordan Times underlines that "shortages in Jordan are worsened by the fact that we share most of the surface water with neighbouring countries" (Nimry, 2013). Al Hamidi writes in the newspaper in Arabic Al Rai that an important aspect of water scarcity is the fact that $90 \%$ of the surface water resources are shared with neighbouring countries. He underlines that the water of the Jordan River cannot be 
used for agricultural or industrial purposes by Jordan due to the continued pollution and violations from the Israeli side (Al Hamidi, 2012). As it emerges in Figure 1, this sub-narrative is relatively less powerful than the population growth, immigration, and refugees' one as it is not often mentioned by donors and international organisations compared to the previous sub-narrative.

Concerning what it is meant by "fair", the interviewees never explicitly referred to international law or to the 1997 United Nations Convention on the Law of the NonNavigational Uses of International Watercourses. Concerning the Jordanian-Syrian hydropolitical relations, fair is perceived as having the bilateral agreement respected and not violated. Concerning the 1994 Jordanian-Israeli treaty, fair was used to describe both the correct implementation of the treaty, as well as to challenge the water allocation among the riparian countries of the Jordan River Basin, which is seen as inequitable by several NGOs and academics (see Messerschmid and Selby, 2015).

Overall, this sub-narrative is constructed and strongly emphasised by the government, and is generally accepted and is aligned with the thoughts of academics, MPs, political parties, media, and NGOs. Donors and international organisations are more lukewarm about this sub-narrative.

\section{The sub-narrative of climate change as an additional pressure}

The third sub-narrative under the water insufficiency narrative sees water scarcity as due to the impacts of climate change and climate variability to the water sector. Those are identified in temperature increases, decrease in precipitation, droughts, and increase in evaporation. These are resulting in a reduced recharge of aquifers and surface water, and in a decrease in the quality of surface and groundwater resources (MoE \& UNDP, 2014: 21).

In the interviews and reports, climate change was mentioned as one of the causes of water scarcity, although not as the major one, but it still emerged as a relevant sub-narrative: climate change was seen as adding a pressure to water scarcity. This aspect emerged during the interviews with academics, ministerial employees, donors, and NGOs (for instance interviews with academics 3, 4, 7, 11, 30, with the MWI staff $8,14,17,18,22$, 42, with donors 16, 28, 45, and with NGOs interview 48)(Earle et al., 2015: 55). In the interviews, no one challenged or denied the impacts of climate change in Jordan. The Ministry of Environment (MoE) and the United Nations Development Programme (UNDP) emphasised this sub-narrative through key 
texts and reports, within and in line with the global discourse of climate change produced by the United Nations Framework Convention on Climate Change (UNFCCC). Texts mentioned as sources for this information are the Jordan National Communication to the UNFCCC (MoE \& UNDP, 2009, 2014), the 2013-2020 Jordan Climate Change Policy (MoE \& UNDP, 2013), and the national water budget reports of the MWI. In light of the second and third national communication to the UNFCCC, the MWI is updating the National Water Strategy to include the impacts of climate change, which were overlooked in the 2008 edition.

The former minister of environment Khalid Irani stated that "at the adaptation front Jordan is facing a severe challenge in water scarcity to be magnified by the impacts of Climate Change," seeing climate change as magnifying and putting an additional pressure to water scarcity (MoE \& UNDP, 2009: 1). Media reproduces several times the governmental position also on this sub-narrative: for instance, Namrouqa emphasised that "expert believe" that "climate change has already caused a 30 per cent reduction in the kingdom's surface water resources" (Namrouqa, 2009a). Also Al Rawashdeh mentions in the newspaper in Arabic Al Rai climate change as contributing to the decrease of the water resources in northern Jordan (Al Rawashdeh, 2011). The environmentalist Wardam describing the initial findings of the mentioned reports on the impact of climate change on the Jordanian water resources, underlines that "the reality check of the expected water situation in the Kingdom is alarming. This is common knowledge, even to schoolchildren in the country, but the exact nature of the combined impact of climate change on the already exhausted water supply has barely been studied" (Wardam, 2009). Jordanian academics' thoughts are also aligned and coincide with the governmental position of seeing climate change as adding a pressure on water scarcity, backing this sub-narrative, as emerges for instance in the words of Al Omari, Salman, and Karablieh from the University of Jordan: "the impact of climate change on water resources and demands in arid and semiarid regions like Jordan is projected to be severe. [...] Challenges that complicate the water situation in Jordan, especially when coupled with the projected negative impacts of climate change" " (Al-Omari, Salman, \& Karablieh, 2014: 2). Donors also reproduce this element in their conferences, reports, and declarations. For instance the German donor agency (GIZ) in their "Management of Water Resources" section, state that "with less than 150 cubic metres of water available per capita each year, Jordan ranks among the world's most water-poor countries. This situation is exacerbated by the impacts of 
climate change" (GIZ website). Also USAID emphasises repeatedly the climate change aspect, for instance stating on their website that "Jordan is among the driest countries in the world, and climate change trends threaten an even more arid future" (USAID website).

\section{The sub-narrative of Jordan as an arid and semi-arid region with low precipitation}

The fourth sub-narrative under the water insufficiency narrative sees the issue of water scarcity as due to the arid and semi-arid territory with low precipitation in which Jordan lies; territory where the precipitation rate is less than $200 \mathrm{~mm}$ in around $90 \%$ of the country. This sub-narrative emerged several times in interviews with academics (interviews 3, 4, 7, 11) and employees, managers, and directors at the MWI and MoA when asked why there is water scarcity in Jordan (interviews 8, 9, 14, 17, 18, 22, 25, and 42).

Academics, NGOs, governmental reports, and donors contribute to reinforce this sub-narrative. For instance, the first paragraph of an academic article of Ghanem, from the University of Jordan, underlines that "a large part of Jordan is arid and semiarid, about $90 \%$ of its area has an annual rainfall totally less than $200 \mathrm{~mm}$ on average, most of it evaporates back to the atmosphere" (Ghanem, 2013: 203). Munther Haddadin, former minister of the MWI, when describing the Middle East and North Africa (MENA) region, also emphasises that the "MENA has the most desert and arid areas per capita" (Haddadin, 2001: 461). The governmental voice reproduced by media emphasises that "Jordan, the world's second water poorest country [...] relies mainly on rainwater, but only 1.1 per cent of its total area receives an average of $400-600 \mathrm{~mm}$ of rain a year, according to official figures. Approximately 91 per cent of Jordan's total area of 97,000 square kilometres is situated in arid areas with an annual rainfall average of 50-200 mm, while 2.9 per cent of the country's land is categorised as semiarid" (Freij, 2014). Jordan is defined in the MWI reports as a "resource-starved" country and "is classified as semi-arid to arid region with annual rainfall of less than $200 \mathrm{~mm}$ over 90\% of the land" (MWI, 2014: 3). Also, Rania Abdel-Khaleq, manager at the MWI, wrote with Dziegielewski in an academic article that "Jordan is a semiarid country with very limited freshwater resources" and went on emphasising the aridity of the country as a cause for its water scarcity (Abdel Khaleq \& Dziegielewski, 2006: 216). Limited precipitation and the arid nature of Jordan were also mentioned as causes of water scarcity in two interviews with donors (interviews 28 and 45), but the 
interviews with donors generally did not focus or even mention aridity as a main cause of water scarcity.

Concerning the texts that are a source of interpretation for this element, the water budget reports of the MWI and the reports of the water research studies unit in the ministry were mentioned by several governmental interviewees in order to show and prove the low precipitation rate in Jordan. This sub-narrative is emphasised by the government, mainly the MWI and its reports, and coincides with the thoughts of different ministries, academics, and a few donors.

\section{THE WATER MISMANAGEMENT NARRATIVE}

This section analyses the water mismanagement narrative, which identifies the reasons for the issue of water scarcity on the mismanagement of the water resources (Rijsberman, 2006: 3). This narrative attributes water scarcity primarily to bad governance and mismanagement of the water sector, and a lack of economic investment and development of the water resources, de-emphasising the causes promoted by the water insufficiency narrative. This section examines the subnarratives comprising this narrative, which are: Non-Revenue Water (NRW) due to leakages and physical losses, NRW due to illegal wells and illegal uses, and the unsustainable agricultural water use. NRW is different from Unaccounted for Water (UFW) because the latter is water produced by a provider but not billed due to losses, illegal uses, and wrong metering. NRW instead includes UFW plus authorised unbilled uses like uses for public buildings, fire-fighting, etc. (IB-NET, 2005). In the case of Jordan most reports use NRW rather than UFW. For this reason, it is more practical to consider NRW rather than UFW for the scope of this article.

\section{The sub-narrative of Non-Revenue Water: leakages and physical losses}

The first sub-narrative under the water mismanagement narrative identifies the main reason for water scarcity in the striking percentage of water resources lost in Jordan because of NRW due to leakages and physical losses. In the interviews with donors and international organisations, NRW due to leakages and physical losses strongly and overwhelmingly emerged as one of the main causes for water scarcity in the country.

Reports, declarations, and studies of donors, international organisations, and water utilities highlight NRW due to leakages and physical losses as a major cause of water scarcity in Jordan. In the interviews, when they were asked about the causes of 
water scarcity in the country, they have always mentioned the elements of this subnarrative as a very important aspect causing water scarcity. For instance, JICA's report underlines that in Jordan "NRW reaching more than $50 \%$ of water produced as of 2002, is becoming an urgent issue" both in urban and agricultural areas (JICA, 2014: 3). Hani Kurdi, Deputy Chief Program Officer of JICA Jordan emphasises that "reducing the high ratio of Non-Revenue Water (NRW) in the networks is one of JICA technical assistance projects" in order to improve "efficient management and effective use of water resources" (JICA, 2014: 6). Also GIZ identified NRW due to leakages and physical losses as a major issue, and has been working through projects aiming at reducing physical losses through improving the pipelines network and the metering system. It has been doing so by involving the private sector and enhancing their participation and partnership with the public sector (Luck, 2008). GIZ's focus is on increasing efficiency by reducing NRW, however focusing more on the physical losses rather than on the illegal uses and losses (ibid.). Also USAID, through the Millennium Challenges Cooperation and the Institutional Support and Strengthening Program (ISSP), focuses on NRW due to leakages and physical losses, and links it to the performance of the water utilities in Jordan. For USAID, the high level of NRW in the case of the water utilities of Miyahuna and Yarmouk Water Company (YWC) means that the performance of the management of the water resources needs to be improved at the company level through institutional reforms (ISSP, 2012a: 31-32). This emerges from the report, which emphasises that "tightly linked to the utility performance [...] is the issue of nonrevenue water" (ISSP, 2012a: 31). Also, "it is essential that skills of the NRW detection and reduction are transferred to the local utility, and that NRW reduction is institutionalised" (ISSP, 2012a: 33). UN agencies and other Western donors also underlined in the interviews that NRW due to leakages and physical losses is a major reason for water scarcity in Jordan (interviews $81,89,32,45,58,59$ ). As the head of the water program of a donor agency said, it makes no sense to pump expensive water from Disi, which is a non-renewable aquifer, for $300 \mathrm{~km}$ to Amman if $50 \%$ is then lost due to leakages and physical losses (interviews 81 and 89 ). The Jordan Times mentioned NRW due to leakages and physical losses only in relation to projects of JICA, USAID, and GIZ relating to improving the pipeline system, or through improvements on the metering system (Ghazal, 2010a, 2010b). Even if the government and the MWI acknowledged this cause as contributing to water scarcity, it was always de-emphasised in reports and during the interviews. As the former minister of the MWI 
Jamani puts it, "even with improving water efficiency, reducing water loss and wisely managing every drop of water, the country will still suffer from a water deficit," calling then for focusing on the causes identified by the water insufficiency narrative (Namrouqa, 2012).

The texts sources of this sub-narrative and mentioned in interviews and reports are: the yearly reports of water utilities; and studies produced by ISSP, which is a USAID/Jordan program for supporting the MWI's efforts to improve the management of the water sector. The blame is on the poor management and bad governance of water resources; blaming mainly the water companies and the public sector institutions Water Authority of Jordan (WAJ) and the Jordan Valley Authority (JVA) within the MWI, which are responsible for water utilities and for the sewage systems in the country.

Overall, the main actors backing this sub-narrative are donors, international organisations, and the water utilities, and they do so through the production of texts, meaning their reports, declarations, and studies.

\section{The sub-narrative of Non-Revenue Water: illegal wells and illegal uses}

The second sub-narrative under the water mismanagement narrative considers NRW due to illegal wells and illegal uses as among the main reasons for water scarcity in Jordan. Until 2013, the focus when discussing NRW was mainly on the water lost due to leakages, while the government and the MWI overlooked the issue of water theft and illegal wells. In August 2013, the new minister of the MWI Hazim Al Nasser started a campaign against illegal wells, which originated new framings of this subnarrative from the governmental officials. While before 2013 only donors, international organisations, and a few academics mentioned NRW due to illegal wells and illegal uses, after 2013 the MWI and the government emphasised it also.

Before 2013, media mentioned NRW in relation to illegal uses and thefts only when reporting declarations of Miyahuna, the Amman Water Company, and their difficulties in collecting revenues and their losses due to illegal connections (Namrouqa, 2008, 2010b). USAID pushed for the MWI to tackle the issue of illegal wells as emerges in the following USAID/Audit report:

Mission officials noted that during negotiations over the draft list of conditions precedent, Government of Jordan officials requested that mission staff remove one 
condition. It required the Government of Jordan to shut down 50 illegal wells. Although closing the illegal wells would increase Jordan's water sustainability by decreasing nonrevenue water, Government of Jordan officials could not achieve the condition precedent because of political pressure from influential agribusiness owners (USAID, 2011: 5-6).

Personnel from the international organisations and donors' agencies emphasised in the interviews that NRW due to illegal wells and uses are a major obstacle for an efficient water sector. On this topic, Hazem Al Nasser, minister of the MWI, in August 2013 launched the so-called "illegal wells campaign". The minister stated that "this is a high-level decision, which calls for respecting the law and achieving justice... nobody has the right to claim that they are above the law, whatever their... political, tribal or social background may be," adding that the objective is to close all illegal wells in the country (Namrouqa, 2013e). Penalties for illegal wells became much higher, and now ministries of interior and police are supporting the campaign, cooperating with the MWI (interview 18 and 42).

Since the campaign, this sub-narrative is not de-emphasised by the government and media anymore, and it became 'talkable', and this emerges from extensive media coverage. For instance, Namrouqa, in 2014 reports the new voice of the MWI, with an article titled " $70 \%$ of water loss in Jordan blamed on theft, illegal usage - ministry" (Namrouqa, 2014a). Also the newspapers in Arabic have been following, reporting on, and reproducing this sub-narrative since 2013. In Al Rai, for instance, several articles appeared emphasising the successes of this campaign, while Wardam in Ad-Dustour has underlined the necessity of continuing with this campaign (Wardam, 2013; Zakarneh, 2015).

\section{The sub-narrative of the unsustainable agricultural water use}

The third sub-narrative under the water mismanagement narrative is that water scarcity is due to the inefficient water management, especially in the agricultural sector, which consumes almost $60 \%$ of the water resources in Jordan. In the interviews with donors and international organisations, the unsustainable agricultural water use emerged strongly and overwhelmingly as an important cause of water scarcity in the country. 
According to this sub-narrative, the agricultural sector is economically not efficient, as it uses around $60 \%$ of the water resources in Jordan, but it contributes with only $3 \%$ to the national gross domestic product (GDP) and it employs less than $4 \%$ of the national labour force (Castejon, 2011: 227; IFC, 2012: 5) ${ }^{5}$. Donors and international organisations highlight in their reports and during the interviews the economic inefficiency of the irrigation techniques, technologies, and type of crops used by farmers, the latter often water intense (interviews 45 and 58) (IFC, 2012: 5; ISSP, 2012b: iii). The low economic incentives set by the high subsidies for water for the agricultural sector does not motivate consumers to increase their water efficiency. As emerges from Table 3, farmers are those paying the least for water, followed by industries, and those using it for domestic use. If the latter run out of water and decide to buy water from private tankers, the price in Amman is 25 Jordanian Dinars (JD) for six cubic meters, which is about four JD per CM.

\section{TABLE 3}

Moreover, donors and international organisations argue that Jordan should be careful in producing agricultural goods for export because of its limited water resources, and it should focus on low water intensive products and with a high economic return (ISSP, 2012b: 28; Hussein, 2016; 2018b). As Al Karablieh and Jabarin from the University of Jordan found in a recent study, "Jordan utilizes large amounts of water in its exports, and in turn, it does not export goods with low water requirements [...]. Therefore, they have to be replaced with either imports or crops that optimize the water resources" (Al-Karablieh, Jabarin, \& Tabieh, 2011: 964). For Talozi, Al Sakaji, and Altz-Stamm, "it is additionally necessary to view the virtual water usage numbers in light of how much is being put towards produce that is exported from Jordan. [...] This raises the policy question of whether Jordan should be producing this quantity of fruits and vegetables, either for export or for its own use, with precious blue water resources that are needed in other sectors" (Talozi, Al Sakaji, \& Altz-Stamm, 2015: 477).

Text sources of this sub-narrative are reports of donors and international organisations (interviews 28, 45, 58, and 59), and a few academic articles (Al- 
Karablieh et al., 2011; ISSP, 2012b). However, governmental officials overlook this aspect of the sub-narrative. This sub-narrative is strongly supported by the concept of virtual water, which argues that water scarce countries like Jordan should save their water resources by relying on import of food and reducing their water allocation to the agricultural sector (Allan, 2002: 165-167). However, this idea is challenged by the discourse of food sovereignty, as some local NGOs like the Arab Group for the Protection of Nature (APN) as well as governmental officials, claim that this could lead Jordan to further decrease its food sovereignty, becoming further dependent on foreign countries outside the region even for food. Therefore, they are calling for strengthening the cooperation among the Arab countries to reach food self-sufficiency not at the country level but at the regional level (APN website, interview 72). The necessity for a regional food sovereignty was underlined by the Jordanian minister of the MoE Taher Shakhshir at the Arab Forum for Environment and Development's (AFED) conference in November 2014 and by the AFED report (Namrouqa, 2013c, 2014b).

\section{CONCLUSION}

This article investigated the discourse of water scarcity in Jordan, answering the guiding question: What are the elements comprising the discourse of water scarcity, including narratives and sub-narratives? It did so by unpacking the discourse and investigating it for analytical purposes through two narratives: water insufficiency and water mismanagement narratives. Within the discourse, it examined the seven subnarratives identified in interviews, academic articles, and reports. The analysis was done by identifying the actors constructing and reproducing the discourse, the key texts, and finally the prominence of to what extent the sub-narratives, narratives, and the discourse are powerful and dominant.

In the analysis, it emerged that the water insufficiency narrative is emphasised by the government and reproduced by academics, NGOs, and to some extent also by donors and international organisations. During the interviews and in the reports, those that emphasised the causes of the water insufficiency narrative, perceived the problem as a technical one: there is water scarcity due to the limited water resources, which makes it difficult to meet the growing demand; consequently, the issue is a technical and de-politicised one: how can we increase the supply in order to meet the demand? It follows that the solutions put forward by those emphasising this narrative are 
engineering and large infrastructural solutions: the Red Sea - Dead Sea Canal project ${ }^{6}$, construction on large dams, and the Disi Canal project.

Instead, the water mismanagement narrative is emphasised by donors and international organisations and since 2013 also the MWI sanctions one sub-narrative. This narrative is reproduced also by other actors, but they are fewer compared to those reproducing the water insufficiency narrative. What is interesting, is to look also at the solutions that those constructing and reproducing this narrative put forward. For them, the issue about water scarcity is that, while water resources would be enough in the country to meet the demand, they are mismanaged. Consequently, the solutions they put forward focus on water demand management: rehabilitation of the supply system; efficiency in water utilities; closure of illegal wells; tariffing system; regulation on type of crops, efficiency in irrigational practices; and awareness raising for behavioural change. Nevertheless, while all supply side solutions - opened by the water insufficiency narrative, are all implemented or at least on the top priority agenda of the MWI; the solutions opened by the water mismanagement narrative are not always implemented. Further research on the water politics of Jordan, exploring power relations in society and interests, would shade lights on the reasons behind these policy decisions.

This article provided an in depth analysis of water scarcity discourse, identifying the elements comprising the discourse of water scarcity. This is important because discourses contribute to shaping policies and hydropolitical relations, and therefore it is essential to firstly investigate the construction of the discourse and the elements comprising the discourse. This article is important for the overall study of water in Jordan as it maps the elements of the discourse, identifying the narratives and the sub-narratives. This is necessary as it allows identification of who is behind the construction of the different narratives and sub-narratives, and it is the starting point for further research on water in Jordan and for elaborating policy recommendations. 


\section{$\underline{\text { REFERENCE LIST }}$}

Abdel Khaleq, R. A., \& Dziegielewski, B. (2006). A national water demand management policy in Jordan. Management of Environmental Quality: An International Journal, $17(2), 216-225$.

Al Hamidi, T. (2012). Specialists: "two seas project" is the only sustainable solution to solve the water scarcity issue Al Rai, 11 October 2012 (in Arabic).

Al Rawashdeh, R. (2011). Wahda Dam, the biggest dam, is still disappointing Al Rai, 18 May 2011 (in Arabic).

Al Rawashdeh, R. (2012a). Jordanians and Syrian refugees share the water shortage problem. Al Rai, 02 September 2012 (in Arabic).

Al Rawashdeh, R. (2012b). Yarmouk River between the illegal Syrian agriculture production and the thirst Wahda Dam. Al Rai, 30 April 2012 (in Arabic).

Al-Jaloudy, M. A. (2006). Country pasture/forage resource profiles. Amman: Ministry of Agriculture.

Al-Karablieh, E., Jabarin, A., \& Tabieh, M. (2011). Jordanian Horticultural export competitiveness from water perspective. Journal of Agricultural Science and Technology, 1(7), 964-974.

Al-Omari, A., Salman, A., \& Karablieh, E. (2014). The Red Dead Canal project: an adaptation option to climate change in Jordan. Desalination and Water Treatment, 52(13-15), 2833-2840.

Alatout, S. (2008). 'States' of scarcity: water, space, and identity politics in Israel, 194859. Environment and Planning D: Society and Space, 26(6), 959-982.

Allan, T. (2002). The Middle East water question: Hydropolitics and the global economy (Vol. 2): Ib Tauris.

Barham, N. (2012). Is Good Water Governance Possible in a Rentier State? The Case of Jordan. Analysis.

Bonn, T. (2013). On the political sideline? The institutional isolation of donor organizations in Jordanian hydropolitics. Water Policy, 15(5), 728-737.

Castejon, J.-M. (2011). Developing Qualifications Frameworks in EU Partner Countries: Modernising Education and Training: Anthem Press.

Dryzek, J. S. (1997). The politics of the earth: Environmental discourses: Oxford University Press. 
Earle, A., Cascao, A. E., Hansson, S., Jägerskog, A., Swain, A., \& Öjendal, J. (2015). Transboundary Water Management and the Climate Change Debate: Routledge.

Edwards, G. A. (2013). Shifting constructions of scarcity and the neoliberalization of Australian water governance. Environment and Planning A,45(8), 1873-1890.

FAO. (2009). Irrigation in the Middle East region in figures: AQUASTAT Survey - 2008

Feitelson, E. (2002). Implications of shifts in the Israeli water discourse for Israeli-Palestinian water negotiations. Political Geography, 21(3), 293-318.

Freij, M. (2014). Recent rainfall 'good news' for farmers, agriculture sector. The Jordan Times(01 November 2014).

Ghanem, A. A. (2013). Case Study: Trends and Early Prediction of Rainfall in Jordan.

Ghazal, M. (2010a). Japan offers help for Jordan's water loss woes. The Jordan Times, 12 November 2010.

Ghazal, M. (2010b). JICA project seeks to reduce water loss percentage. The Jordan Times, 16 November 2010.

Hadadin, N., Qaqish, M., Akawwi, E., \& Bdour, A. (2010). Water shortage in Jordansustainable solutions. Desalination, 250(1), 197-202.

Haddadin, M. J. (2001). Water scarcity impacts and potential conflicts in the MENA region. Water international, 26(4), 460-470.

Haddadin, M. J. (2006). Water resources in Jordan: evolving policies for development, the environment, and conflict resolution: Resources for the Future.

Haddadin, M. J. (2012). Diplomacy on the Jordan: International conflict and negotiated resolution (Vol. 21): Springer Science \& Business Media.

Hajer, M. A. (1995). The politics of environmental discourse: ecological modernization and the policy process (p. 40). Oxford: Clarendon Press.

Hussein, H. (2016). An analysis of the discourse of water scarcity and hydropolitical dynamics in the case of Jordan. PhD Thesis, University of East Anglia.

Hussein, H. \& Grandi, M. 2015. Contexts Matter: A Hydropolitical Analysis of Blue Nile and Yarmouk River Basins. Social Water Studies in the Arab Region, 159.

Hussein, H. \& Grandi, M. 2017. Dynamic political contexts and power asymmetries: the cases of the Blue Nile and the Yarmouk Rivers International Environmental Agreements: Politics, Law and Economics.

Hussein, H. 2017a. Politics of the Dead Sea Canal: a Historical Review of the Evolving Discourses, Interests, and Plans. Water International, Vol. 42, issue 5. $10.1080 / 02508060.2017 .1344817$ 
Hussein, H. 2017b. A critique of water scarcity discourses in educational policy and textbooks in Jordan, The Journal of Environmental Education.

Hussein, H. 2017c. Whose 'reality'? Discourses and hydropolitics along the Yarmouk River. Contemporary Levant,2(2), 103-115.

Hussein, H. 2018a. Yarmouk, Jordan, and Disi basins: Examining the impact of the discourse of water scarcity in Jordan on transboundary water governance. Mediterranean Politics, 1-21.

Hussein, H. 2018b. Tomatoes, tribes, bananas, and businessmen: An analysis of the shadow state and of the politics of water in Jordan. Environmental Science \& Policy,84, 170176.

ICRC. (2015). Bled Dry: How war in the Middle East is bringing the region's water supplies to breaking point. An ICRC report.

IFC. (2012). Socio-Economic Impact of IFC Financing in Jordan - An Assessment of Employment and Value-added -.

ISSP. (2012a). Water valuation study: disaggregated economic value of water in industry and irrigated agriculture in Jordan

ISSP. (2012b). Water valutation study - summary report, disaggregated economic value of water in industry and irrigated agriculture in Jordan

ISSP. (2014). Analysis report: socio-economic survey of groundwater wells in Jordan

JICA. (2014). JICA's Cooperation for Water Sector in Jordan. 30 years history of remarkable achievements.

Khouri, R. G. (1981). The Jordan valley: Life and society below sea level: Longman London and New York.

Leach, M., \& Mearns, R. (1996). The Lie of the Land: challenging received wisdom on the African environment: James Currey Ltd.

Luck, T. (2008). GTZ unites private and public sectors to combat water loss. The Jordan Times, 31 July 2008.

Mehta, L. (2001). The manufacture of popular perceptions of scarcity: dams and water-related narratives in Gujarat, India. World Development, 29(12), 2025-2041.

Messerschmid, C., \& Selby, J. (2015). Misrepresenting the Jordan River Basin. Water Alternatives, $8(2)$.

Miller, E. (2012). Jordanian farmers: Israel is stealing our water. The Times of Israel, 31 August 2012. 
Ministry of Education. (2013). Textbook of Geography, 10th grade, first part (in Arabic).

MoE, \& UNDP. (2009). Jordan's Second National Communication to the United Nations Framework Convention on Climate Change (UNFCCC).

MoE, \& UNDP. (2013). The National Climate Change Policy of the Hashemite Kingdom of Jordan 2013-2020

MoE, \& UNDP. (2014). Jordan's Third National Communication on Climate Change.

MWI. (2009). Water for Life. Jordan's Water Strategy 2008-2022.

MWI. (2013). Cost of hosting Syrian refugees on water sector of Jordan.

MWI. (2014). Establishing the Post-2015 Development Agenda: Sustainable Development Goals (SDG) towards Water Security The Jordanian Perspective.

MWI, \& GTZ. (1977). National Water Master Plan of Jordan. Main Report, Atlas. Frankfurt: German Agency for Technical Cooperation.

Namrouqa, H. (2008). Crackdown on illegal water use continues. The Jordan Times, 11 June 2008.

Namrouqa, H. (2009a). Lack of funding, governance compound Kingdom's water woes. The Jordan Times, 08 June 2009.

Namrouqa, H. (2009b). Water officials attacked in Ajloun. The Jordan Times, 14 September 2009.

Namrouqa, H. (2010a). 'Jordan does not owe Israel a drop of water'. The Jordan Times, 05 March 2010.

Namrouqa, H. (2010b). Large-scale theft posing threat to capital's water supply - Miyahuna. The Jordan Times, 9 June 2010.

Namrouqa, H. (2012). Jordan's critical water situation highlighted The Jordan Times, 19 March 2012.

Namrouqa, H. (2013a). \$108m project to revamp Zarqa water network launched. The Jordan Times, 31 march 2013.

Namrouqa, H. (2013b). Authorities brace for 'unprecedented' water demand in summer across Jordan. The Jordan Times, 25 May 2013.

Namrouqa, H. (2013c). Experts to draw up regional food security policies. The Jordan Times, 11 September 2013.

Namrouqa, H. (2013d). Fatwa prohibiting water theft issued. The Jordan Times, 4 December 2013.

Namrouqa, H. (2013e). New campaign launched to curb water violations. The Jordan Times, 5 August 2013. 
Namrouqa, H. (2014a). 70\% of water loss in Jordan blamed on theft, illegal usage — ministry. The Jordan Times, 27 January 2014.

Namrouqa, H. (2014b). Achieving food self-sufficiency requires serious regional cooperation — Shakhshir. The Jordan Times, 26 November 2014.

Namrouqa, H. (2014c). Illegal wells in Al Lubban sealed under agreement with tribal leaders. The Jordan Times, 16 August 2014.

Namrouqa, H. (2014d). Jordan world's second water-poorest country. The Jordan Times, 22 October 2014.

Nimry, H. (2013). Water stress in Jordan. The Jordan Times, 29 December 2013.

Rijsberman, F. R. (2006). Water scarcity: Fact or fiction? Agricultural water management, $80(1), 5-22$.

Saif, I., \& Omet, G. (2005). The Fiscal Impact of Aid in the Case of the Jordanian Economy. Paper presented at the Economic Research Forum 12th Annual Conference.

Selby, J. (2005). The geopolitics of water in the Middle East: fantasies and realities. Third World Quarterly, 26(2), 329-349.

Selby, J. (2003). Water, power and politics in the Middle East: The other Israeli-Palestinian conflict. IB Tauris.

Talozi, S., Al Sakaji, Y., \& Altz-Stamm, A. (2015). Towards a water-energy-food nexus policy: realizing the blue and green virtual water of agriculture in Jordan. International Journal of Water Resources Development, 31(3), 461-482.

USAID. (2011). Audit of USAID/Jordan's design for sustainability in its water resources program.

Wardam, B. (2004). More politics then water: Water rights in Jordan. IUCN Regional Water Programme in West Asia and North Africa, Jordan, Global Issue Papers, Heinrich Böll Foundation.

Wardam, B. (2009). Water planning in Jordan disregards climate change. The Jordan Times, 22 June 2009.

Wardam, B. (2013). Fighting water theft: silence is not possible anymore. Ad-Dustour, 11 November 2013 (in Arabic).

Yorke, V. (2013). Politics matter: Jordan's path to water security lies through political reforms and regional cooperation. NCCR Trade Regulation, Working Paper 2013/19.

Yorke, V. (2016). Jordan's shadow state and water management: prospects for water security will depend on politics and regional cooperation. In Society-Water-Technology (pp. 227-251). Springer International Publishing. 
Zakarneh, K. (2015). The MWI reveals details on new violations on water lines. Ad-Dustour, 10 August 2015 (in Arabic).

Zeitoun, M. (2008). Power and water in the Middle East: The hidden politics of the Palestinian-Israeli water conflict. IB Tauris. 